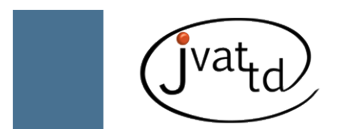

\title{
PP65 antigenemia in the diagnosis of cytomegalovirus infection in AIDS patients
}

\author{
Capela RC (1), Grassi A (2), Souza LR (1)
}

(1) Department of Tropical Diseases, Botucatu Medical School, São Paulo State University (UNESP - Univ Estadual Paulista), Botucatu, São Paulo State, Brazil; (2) Amaral Carvalho Hospital, Jaú, São Paulo State, Brazil.

\begin{abstract}
Cytomegalovirus causes significant morbidity and mortality in AIDS patients and those having undergone bone marrow or another transplant. PP65 antigenemia is based on detecting viral antigen in peripheral blood leukocytes through immunochemistry and by monitoring the infection in immunocompromised individuals. The present study aimed to set up this diagnostic technique in AIDS patients with active cytomegalovirus infection and verify its occurrence in the Botucatu region of São Paulo state, Brazil. Fifty patients, 35 men and 15 women aged from 24 to 69 years, were recruited from those attended at the Department of Tropical Diseases of Botucatu Medical School, UNESP, and divided into three groups according to $\mathrm{CD}_{4}^{+} \mathrm{T}$ lymphocyte counts and antiretroviral treatment. The control group comprised bone marrow transplant patients. Fourteen AIDS patients with low $\mathrm{CD}_{4}{ }^{+}$cell counts tested positive for PP65 antigenemia, which could predict cytomegalovirus infection and indicate prophylactic treatment.
\end{abstract}

Key words: acquired immunodeficiency syndrome, cytomegalovirus, pp65 antigen, laboratory diagnosis.

\section{INTRODUCTION}

Cytomegalovirus (CMV), the commonest opportunistic viral pathogen found in AIDS and bone marrow and other organ transplant patients, causes significant morbidity and mortality. Studies conducted before and after the introduction of highly active antiretroviral therapy (HAART) have consistently identified CMV viremia as a predictor of mortality, independent of absolute CD4 T-cell count and HIV viral load. The clinical manifestations of CMV disease are related to lesion location and include retinitis, gastrointestinal tract problems, hepatitis, pneumonia, myocarditis, and changes in the central and peripheral nervous systems (1-4). Diagnosis of active CMV infection in immunodepressed patients is hampered by the fact that they are often infected without any clinical symptoms. Fast detection methods for CMV viremia include: the antigenemia assay for detecting PP65 antigen in polymorphonuclear leukocytes from peripheral blood, polymerase chain reaction (PCR), nucleic acid sequencebased amplification (NASBA), and molecular methods such as branched-DNA signal amplification assay (b-DNA) and hybrid capture.

Blank et al. (5) demonstrated that PP65 antigenemia assay is sensitive, specific, easy to perform, and does not require special equipment, thereby allowing indirect quantification of CMV in leukocytes from AIDS and bone marrow transplant patients. Early diagnosis of active CMV infection is related to the increased number of PP65 antigenemia-positive cells in leukocytes, which can occur three months before disease development (6-10). Antigenemia is used as a tool to monitor disease caused by CMV in bone 
marrow and solid organ transplant patients (11, 12). The objective of this work was to adopt the PP65 antigenemia technique for laboratory diagnosis of active CMV infection in AIDS patients at the Tropical Disease Experimental Laboratory, Botucatu Medical School, São Paulo State of University (UNESP), and evaluate the occurrence of this infection in the Botucatu region of São Paulo state, Brazil.

\section{PATIENTS AND METHODS}

Fifty confirmed AIDS patients were recruited, having been attended at the Department of Tropical Diseases, Botucatu Medical School, UNESP, between December 2004 and December 2005. Thirty-five (70\%) were male and 15 (30\%) female, with a mean age of 41.1 years (varying from 24 to 69 years). A control group was also studied, consisting of 34 bone marrow transplant patients from the Amaral Carvalho Hospital in Jaú, Brazil, of which 21 (61.8\%) were male and 13 (38.2\%) female. The present work was approved by the Research Ethics Committee of Botucatu Medical School of UNESP.

Inclusion criteria for AIDS patients were adults from either sex, with confirmed AIDS diagnosis, aged 18 years or more, who at the time of selection had undergone $\mathrm{CD}_{4}^{+} \mathrm{T}$ lymphocyte determination, and gave their written informed consent to participate in this study. They were divided into the following groups: Group G1: 18 individuals with AIDS, $\mathrm{CD}_{4}^{+} \mathrm{T}$ lymphocyte cell count $<100$ cells $/ \mathrm{mm}^{3}$, without antiretroviral treatment. Group G2: 17 individuals with AIDS, $\mathrm{CD}_{4}^{+} \mathrm{T}$ lymphocyte cell count $<100$ cells $/ \mathrm{mm}^{3}$, having received antiretroviral treatment. Group G3: 15 individuals with AIDS, $\mathrm{CD}_{4}^{+}$T lymphocyte cell count $>100$ cells $/ \mathrm{mm}^{3}$, and with and without having received antiretroviral treatment. Group G4: 34 bone marrow transplant individuals independent of the CD4+ $\mathrm{T}$ lymphocyte cell count.

Suspected CMV infection was defined in AIDS patients as the presence of clinical signs suggestive of adrenal compromise or the presentation of retinitis with the characteristic lesions. CMV infection was considered confirmed in those presenting positive culture or cytomegalic inclusion found in tissue submitted to histopathology.

Laboratory diagnosis of human immunodeficiency virus (HIV) infection was by enzyme immunoassay (ELISA) in two serum samples from each patient to detect TYPE 1 and $2 \mathrm{HIV}$ antibodies. Flow cytometry was used to count $\mathrm{CD}_{4}^{+} \mathrm{T}$ lymphocytes, and results were expressed as the absolute number of cells $/ \mathrm{mm}^{3}$. These exams were performed at the UNESP Blood Center in Botucatu.

Antiretroviral treatment was indicated as per the Brazilian Ministry of Health National DST/ AIDS program (13).

\section{Antigenemia Assay}

This technique was performed as described by van der Bij et al. (2), in 1988, with a few modifications. Detecting PP65 antigen requires $4 \mathrm{~mL}$ of blood by venopuncture collected with EDTA anticoagulant, with the addition of $2 \mathrm{~mL}$ of dextran in a conical plastic tube to separate the supernatant containing polymorphonuclear leukocytes. The pellet obtained was resuspended in phosphate buffer at a final concentration of 3 x $10^{6}$ per mL. Monoclonal (Clonab $\mathrm{CMV}^{\oplus}$ pp 65, Bio-Rad, Germany) and conjugate peroxidase were used.

A slide was stained with Mayer's hematoxylin and read under light microscope; the sample was considered positive when it showed at least one cell with the nucleus or perinuclear membrane stained red or brown. The presence of cells with the nucleus stained blue and cytoplasm stained brown was defined as a negative slide. The reaction was considered false positive when any cell presented cytoplasm stained only light brown (endogenous peroxidase). Slides were read by two different observers under a double blinded scheme without either knowing the result of the other's evaluation. Observer one was an experienced biologist who has routinely used this method in the Antigenemia Laboratory at the Amaral Carvalho Hospital. Observer two was a biologist who had been trained by observer one before the start of the study, and who installed the method at the Tropical Diseases Experimental Laboratory.

\section{Statistical Analysis}

Frequency comparisons in the same sample were made by the binomial test and comparison of medians in dependent samples by the Wilcoxon test. Frequency comparisons in independent samples were by the $\chi^{2}$ and Fisher's exact tests. 
The statistical analyses permitted a probability of a type I error less than or equal to 0.05 to reject a null hypothesis.

\section{RESULTS}

The study groups presented a homogenous gender distribution (Table 1). There was a predominance of males in the study groups without a significant inter-group difference. Among the $50 \mathrm{HIV}$ or AIDS patients studied, only 14 presented PP65 antigenemia, while in the transplanted group none tested positive.

There was significant difference between the patients with HIV or AIDS and those with bone marrow transplants who tested positive for PP65 antigenemia.

Patients in Groups G1 and G2 who presented $\mathrm{CD}^{+} \mathrm{T}$ lymphocyte counts below 100 cells/ $\mathrm{mm}^{3}$ had a higher number of PP65 antigenemianegative cases than Group G3. The antigenemiapositive frequency in HIV/AIDS patients did not differ among the three study groups (Table 2).

There was no difference between independent observers for PP65 antigen neutrophil quantification and $\mathrm{CD}_{4}^{+} \mathrm{T}$ lymphocyte counts below or above 100 cells $/ \mathrm{mm}^{3}$, in AIDS patients with or without antiretroviral treatment and in bone marrow transplant patients.

Evaluation of the $14 \mathrm{HIV} / \mathrm{AIDS}$ patients with positive PP65 antigemenia revealed that only two presented symptoms of cytomegalovirosis (Table 3). The number of PP65 positive neutrophils was less than ten in 13 of these 14 cases. The only patient with confirmed cytomegalovirosis diagnosis by cutaneous lesion histopathology presented a negative PP65 evaluation in an exam performed after treatment with ganciclovir, which is specific for this virus. Six patients with $\mathrm{CD} 4^{+} \mathrm{T}$ cell counts above 100 were found with neutrophils positive for PP65 and the highest number of cells ( 21 cells) was found in one of these patients. All patients with lymphocyte counts below 100 cells/ $\mathrm{mm}^{3}$ presented only 1 to 5 cells positive for PP65.

\section{DISCUSSION}

This study analyzed 50 HIV/AIDS patients with and without antiretroviral treatment and with $\mathrm{CD}_{4}^{+} \mathrm{T}$ lymphocyte counts above and below 100 cells $/ \mathrm{mm}^{3}$, the latter situation having a predisposition to many opportunistic infections including more serious ones like cytomegalovirosis. Thirty-four bone marrow transplant patients were also analyzed as this also presents a risk of infection by CMV.

AIDS patients with less than $100 \mathrm{CD}_{4}^{+}$cells per cubic millimeter were included in the study before antiretroviral treatment. G2 patients, who also presented AIDS and less than $100 \mathrm{CD}_{4}^{+}$ cells per cubic millimeter, were on antiretroviral treatment but had revealed treatment failure. The group with and without antiretroviral treatment and more than $100 \mathrm{CD}_{4}^{+}$cells per cubic millimeter (G3), included patients who were not indicated for treatment as their $\mathrm{CD}_{4}^{+}$cell counts were found to be over 200 per cubic millimeter. Therefore, most patients were in the advanced stage of the disease, without having received antiretrovirals or with treatment failure, with a high possibility

Table 1. Group and gender distributions of 50 HIV infected patients and 34 bone marrow transplant patients

\begin{tabular}{c|c|c|c}
\hline & \multicolumn{2}{|c}{ Gender } & \\
\hline Group & $\begin{array}{c}\text { Male } \\
(\mathbf{n} \mid \%)\end{array}$ & $\begin{array}{c}\text { Female } \\
(\mathbf{n} \mid \%)\end{array}$ & $\begin{array}{c}\text { Total } \\
\text { (n } / \%)\end{array}$ \\
\hline G1 & $14 \mid 77.8$ & $4 \mid 22.2$ & $18 \mid 100.0$ \\
\hline G2 & $11 \mid 64.7$ & $6 \mid 35.3$ & $17 \mid 100.0$ \\
\hline G3 & $10 \mid 66.7$ & $5 \mid 33.3$ & $15 \mid 100.0$ \\
\hline G4 & $21 \mid 61.8$ & $13 \mid 38.2$ & $34 \mid 100.0$ \\
\hline Total & $56 \mid 66.7$ & $28 \mid 33.3$ & $84 \mid 100.0$ \\
\hline
\end{tabular}

G1: CD4 ${ }^{+}$T lymphocyte cell count $<100$ cells $/ \mathrm{mm}^{3}$, without antiretroviral treatment; G2: CD4 ${ }^{+}$T lymphocyte cell count $<100$ cells/ $\mathrm{mm}^{3}$, and with antiretroviral treatment; G3: CD4 ${ }^{+} \mathrm{T}$ lymphocyte cell count $>100$ cells $/ \mathrm{mm}^{3}$, and with and without antiretroviral treatment; G4: bone marrow transplant patients.

No statistically significant difference among groups ( $p>0.05)$. 
Table 2. Distribution of HIV/AIDS patients according to presence of PP65 antigenemia $(n=50)$

\begin{tabular}{c|c|c|c}
\hline Groups & $\begin{array}{c}\text { Positive } \\
\mathbf{n}(\mathbf{2 7 . 7 \% )}\end{array}$ & $\begin{array}{c}\text { Negative } \\
\mathbf{n}(\mathbf{7 2 . 3 \% )}\end{array}$ & $\begin{array}{c}\text { Total } \\
\mathbf{n}(\mathbf{1 0 0 \% )})\end{array}$ \\
\hline G1 & 5 & 13 & 18 \\
\hline G2 & 3 & 14 & 17 \\
\hline G3 & 6 & 9 & 15 \\
\hline Total & 14 & 36 & 50 \\
\hline
\end{tabular}

G1: CD4 ${ }^{+}$T lymphocyte cell count $<100$ cells $/ \mathrm{mm}^{3}$, without antiretroviral treatment; G2: CD4 ${ }^{+}$T lymphocyte cell count $<100$ cells/ $\mathrm{mm}^{3}$, and with antiretroviral treatment; G3: CD4 ${ }^{+} \mathrm{T}$ lymphocyte cell count $>100$ cells $/ \mathrm{mm}^{3}$, and with and without antiretroviral treatment.

Contrasts: Exact Fisher Test $\mathrm{G} 1=\mathrm{G} 2(\mathrm{p}>0.05) ;(\mathrm{G} 1+\mathrm{G} 2)=\mathrm{G} 3(\mathrm{p}>0.05)$.

Table 3. Distribution of HIV/AIDS patients according to clinical and laboratory characteristics $(n=14)$

\begin{tabular}{c|c|c|c|c}
\hline Patient & Group & $\begin{array}{c}\mathrm{CD}_{4}^{+} \mathbf{T} \\
\text { lymphytes }(\mathbf{n} / \\
\left.\mathbf{m m}^{3}\right)\end{array}$ & $\begin{array}{c}\text { Clinical symptoms } \\
\text { suggesting } \\
\text { cytomegalovirosis }\end{array}$ & PP65 positive cells (n) \\
\hline 1 & 1 & 6 & No & 1 \\
\hline 2 & 1 & 97 & No & 3 \\
\hline 3 & 1 & 10 & No & 3 \\
\hline 4 & 1 & 58 & Yes & 2 \\
\hline 5 & 1 & 2 & No & 3 \\
\hline 6 & 2 & 46 & No & 3 \\
\hline 7 & 2 & 66 & No & 1 \\
\hline 8 & 2 & 11 & No & 4 \\
\hline 9 & 3 & 221 & No & 3 \\
\hline 10 & 3 & 391 & No & 21 \\
\hline 11 & 3 & 146 & No & 3 \\
\hline 13 & 3 & 290 & No & 1 \\
\hline 14 & 3 & 425 & No & 3 \\
\hline
\end{tabular}

of presenting opportunistic infections including cytomegalovirosis (14-16).

The number of evaluated leukocytes varies according to the author consulted and must be between $5 \times 10^{4}$ and $2 \times 10$. We considered $3 \times 10^{5}$ leukocytes to be adequate for this study $(8,17)$.

Another aspect which varied according to the consulted work is the positivity criterion. In our study, finding just one stained cell was a sufficient definition of positivity, but Landry and Ferguson (18) defined a low antigenemia level as a number of positive cells between one and ten, intermediate between 11 and 50, and elevated when over 50 . They observed that most individuals with a low antigenemia level were asymptomatic or were on CMV-specific treatment. In our study, 14 AIDS patients presented study-positive PP65 antigenemia, however 13 presented with less than 10 positive cells and only one patient exceeded ten. This latter patient revealed a $\mathrm{CD}_{4}^{+} \mathrm{T}$ lymphocyte count greater than 200 cells $/ \mathrm{mm}^{3}$ and did not present clinical signs suggesting CMV infection.

The importance of testing for pp 65 antigenemia in AIDS patients with low $\mathrm{CD}_{4}^{+}$cell counts is, 
according to Dodt et al. (19), that a positive exam result can predict infection by CMV well before disease development, which could indicate its prophylaxis. Torrús et al. (16) observed that $26.3 \%$ of patients with positive antigenemia tests developed the disease and that the time between first positive test and cytomegalovirosis diagnosis was 102 days, suggesting that the test is a good early marker for the disease. A similar result was found by Blank et al. (20) where positive antigenemia was seen in AIDS patients three months before they developed the disease caused by CMV.

Antigenemia pp65 was performed only once in our study, and not repeated to monitor patients at high risk of developing the disease caused by CMV, as suggested by some cited authors $(2,16)$.

The et al. (21) argued that repeated PP65 antigenemia testing at short intervals, at least weekly, was important in bone marrow transplant patients for diagnosing CMV activity and indicating treatment as early as possible. There is no precise indication of the ideal interval to repeat the test in AIDS patients; however, Francisci et al. (22) suggested an interval of 4 to 6 months when negative and three months when positive. They also suggested performing a course of anti-CMV specific treatment, following prophylaxis. Perhaps the antigenemia assay should be performed repeatedly on AIDS patients whose $\mathrm{CD}_{4}^{+} \mathrm{T}$ lymphocyte counts remain below 100 cells per $\mathrm{mm}^{3}$, when the risk of CMV infection is higher (22). There is evidence, however, that even in patients whose count remains below this level, but are on a potent antiretroviral treatment program, the incidence of opportunistic infections is low due to the presence of a virological response to treatment, or that control of plasmatic viremia from HIV is kept below the detection limit, or at least below 10,000 copies per $\mathrm{mL}$ or $\log 4.0$.

The present study found a small number of cells positive for CMV pp65 antigen in all 14 patients, and only two of them presented clinical signs suggesting the infection. According to Landry and Ferguson (18) and Mazzulli et al. (23), finding less than ten positive cells generally occurs in asymptomatic patients, which was also seen in our study. The latter authors, who found positive antigenemia in all patients clinically presenting infection by CMV and in those with suspected infection, suggested repeating the exam after 10 days.
Our intention is to use the pp65 antigenemia technique from this study in routine consultations with AIDS patients seen at the AIDS Day Hospital at the Botucatu Medical School, UNESP, to perform early diagnosis and monitoring, with periodically repeated tests for active infection caused by CMV in AIDS patients, the aim being to provide disease prophylaxis or early treatment.

The present work has a few limitations, since antigenemia testing was performed only once for each patient and was not compared with other methods like PCR.

\section{ACKNOWLEDGEMENTS}

The authors would like to thank the Amaral Carvalho Hospital in Jaú, SP, and the Blood Center of Botucatu Medical School, UNESP, Botucatu, SP, Brazil.

\section{COPYRIGHT \\ (C) CEVAP 2012}

\section{SUBMISSION STATUS}

Received: August 2, 2011.

Accepted: November 3, 2011.

Abstract published online: November 3, 2011.

Full paper published online: February 28, 2012.

\section{CONFLICTS OF INTEREST}

The authors declare no conflicts of interest.

\section{FINANCIAL SOURCE}

The State of São Paulo Research Foundation (FAPESP, grant n. 0312374-0) provided the financial grants.

\section{ETHICS COMMITTEE APPROVAL}

The present study was approved by the Research Ethics Committee (CEP) of the Botucatu Medical School, UNESP, under the protocol number $234 / 2002$.

\section{CORRESPONDENCE TO}

Lenice do Rosário de Souza, Departamento de Doenças Tropicais e Diagnóstico por Imagem, Faculdade de Medicina de Botucatu, UNESP, Distrito de Rubião Júnior, s/n, Botucatu, SP, 18618-970, Brasil. Phone: +55 14 3811-6212. Fax: +55 14 3815-9898. Email: lsouza@fmb.unesp.br.

\section{REFERENCES}

1. Jacobson MA, Mills J. Serious cytomegalovirus disease 
in the acquired immunodeficiency syndrome (AIDS). Clinical findings, diagnosis and treatment. Ann Intern Med. 1988;108(4):585-94.

2. van der Bij W, Schirm J, Torensma R, J van Son W, Tegzess AM, The TH. Comparison between viremia and antigenemia for detection of cytomegalovirus in blood. J Clin Microbiol. 1988;26(12):2531-5.

3. Drew WL. Cytomegalovirus infection in patients with AIDS. Clin Infect Dis. 1992;14(2):608-15.

4. Deayton JR, Prof Sabin CA, Johnson MA, Emery VC, Wilson P, Griffiths PD. Importance of cytomegalovirus viraemia in risk of disease progression and death in HIV-infected patients receiving highly active antiretroviral therapy. Lancet. 2004;363(5259):211621.

5. Blank BSN, Meenhorst PL, Mulder JW, Weverling GJ, Putter H, Pauw W, et al. Value of different assays for detection of human cytomegalovirus (HCMV) in predicting the development of HCMV disease in human immunodeficiency virus - infected patients. J Clin Microbiol. 2000;38(2):563-9.

6. Lipson SM, Kaplan MH, Tseng LF, Mandel FS. Use of the cytomegalovirus antigenemia (CMV-Ag) assay for the detection of CMV in the blood of AIDS patients. Can J Microbiol. 1993;39(11):1059-65.

7. Yen-Lieberman B. Diagnosis of human cytomegalovirus disease. Clin Microbiol Newsletter. 2000;22(14):105-9.

8. Shibata D, Martin WJ, Appleman MD, Causey DM, Arnhein N. Detection of cytomegalovirus DNA in peripheral blood of patients infected with human immunodeficiency virus. $J$ Infect Dis. 1988;158(6):1185-92.

9. Cariani EP, Pollara CP, Valloncini B, Perandin F, Bonfanti C, Manca N: Relationship between pp65 antigenemia levels and real-time quantitative DNA PCR for human cytomegalovirus (HCMV) management in immunocompromised patients. BMC Infect Dis. 2007;7:138.

10. Spector SA, Merrill R, Wolf D, Dankner WM. Detection of human cytomegalovirus in plasma of AIDS patients during acute visceral disease by DNA amplification. J Clin Microbiol. 1992;30(9):2359-65.

11. Baldanti F, Lilleri D, Gerna G. Monitoring human cytomegalovirus infection in transplant recipients. J Clin Virol. 2008;41(3):237-41.

12. Gerna G, Lilleri D. Monitoring transplant patients for human cytomegalovirus: diagnostic update. Herpes. 2006;13(1):4-11.

13. MinistériodaSaúde.SecretariaExecutiva.Coordenação Nacional de DST e AIDS. Recomendações para terapia anti-retroviral em adultos e adolescentes infectados pelo HIV. Brasília ( DF); 2002-2003 e 2004.
14. Gérard L, Leport C Flandre P, Houhou N, SalmonCéron D, Pépin JM, et al. Cytomegalovirus $(\mathrm{CMV})$ viremia and $\mathrm{CD} 4+$ lymphocyte count as predictors of CMV disease in patients infected with human immunodeficiency virus. Clin Infect Dis. 1997;24(5):836-40.

15. Springer K, Weinberg A. Citomegalovirus infection in the era of HAART: fewer reactions and more immunity. J Antimicrob Chemother. 2004;54(3):5826.

16. Torrús D, Portilla J, Hernández-Aguado I, Boix V, Plazas J, Gimeno A, et al. Usefulness of pp65 antigenemia for the early diagnosis of cytomegalovirus disease in patients with AIDS. Eur J Clin Microbiol Infect Dis. 1999;18(9):630-5.

17. Madhavan HN, Samson MY, Ishwarya M, Vijayakumar $\mathrm{R}$, Jambulingam M. PP65 antigenemia and real time polymerase chain reaction (PCR) based-study to determine the prevalence of human cytomegalovirus (HCMV) in kidney donors and recipients with followup studies. Virol J. 2010;7:322-8.

18. Landry ML, Fergunson D. Comparison of quantitative cytomegalovirus antigenemia assay with culture methods and correlation with clinical disease. J Clin Microbiol. 1993;31(11):2851-6.

19. Dodt KK, Jacobson PH, Hofmann B Meyer C, Kolmos HJ, Skinhoj P, et al. Development of cytomegalovirus (CMV) disease may be predicted in HIV infected patients by CMV polimerase chain reaction and the antigenemia test. AIDS. 1998;11(3):F21-8.

20. Blank BSN, Meenhorst PL, Weverling GJ, StoutZonneveld AAMS, Pauw W, Mulder JW, et al. Quantitative pp65-antigenemia assay for the prediction of human cytomegalovirus disease in HIVinfected patients. AIDS. 1999;13(18):2533-9.

21. The TH, van der Ploeg M, van der Berg AP, Vlieger AM, van der Giessen M, van Son WJ. Directed detection of cytomegalovirus in peripherial blood leukocytes - a review of the antigenemia assay and polymerase chain reaction. Transplantation. 1992;54(2):193-8.

22. Francisci D, Tosti A, Baldelli F, Stagni G, Pauluzzi S. The pp65 as a predictor of cytomegalovirus- induced end-organ disease in patient with AIDS. AIDS. 1997;11(11):1341-5.

23. Mazzulli T, Rubin RH, Ferraro MJ, D’Aquila RT, Doveikis AS, Smith BR, et al. Cytomegalovirus Antigenemia: clinical correlations in transplant recipients and in persons with AIDS. J Clin Microbiol. 1993;31(10):2824-7. 